\title{
China's Oil Security in the Context of Energy Revolution: Changes in Risks and the Hedging Mechanism
}

\author{
Haiyu Xie \\ School of Governance, Technical University of Munich, Munich, Germany \\ Email: haiyuxie@zedat.fu-berlin.de
}

How to cite this paper: Xie, H. Y. (2021). China's Oil Security in the Context of Energy Revolution: Changes in Risks and the Hedging Mechanism. American Journal of Industrial and Business Management, 11, 984-1008.

https://doi.org/10.4236/ajibm.2021.119060

Received: August 24, 2021

Accepted: September 15, 2021

Published: September 18, 2021

Copyright (c) 2021 by author(s) and Scientific Research Publishing Inc. This work is licensed under the Creative Commons Attribution International License (CC BY 4.0).

http://creativecommons.org/licenses/by/4.0/

\begin{abstract}
Does China's energy revolution strengthen or weaken its oil security? This study analyzes how the energy revolution influences China's oil security by exploring the changes in risks and the hedging mechanism. China proposed the energy revolution in 2014, committed to carbon peak by 2030 and carbon neutrality by 2060 , aiming to accelerate its energy transition. Meanwhile, China has a high oil import dependency due to its rapid economic development and lack of domestic oil resources, which challenges its oil security. The government and the national oil companies (NOCs) are the main actors to ensure China's oil supply. Based on the interactions between the government and the NOCs, the overseas oil investments and the domestic oil production and strategic petroleum reserves, together with the maritime oil transportation and continental pipelines, provide alternatives for China's oil supply in general and in wartime in particular, thus forming the hedging mechanism for China's oil security. Notably, the energy revolution alters the way energy and geopolitics interact, and the development of renewables in China and other states in the world mitigates geopolitical risks by making China and the world less dependent on unstable oil production regions. Lastly, the energy revolution triggers changes in the hedging mechanism for China's oil security due to the buildup of oil reserves including the commercial oil reserves, the arduous development of domestic oil output, and the drop in overseas oil investments but increase in foreign renewables investments. And thus, China's oil security and its capabilities to respond to potential oil supply interruptions have changed accordingly. This paper not only contributes to understanding China's oil security in the context of the energy revolution by analyzing the changes in the hedging mechanism, but also stimulates thinking about the impacts of the energy transition on fossil energy security.
\end{abstract}




\section{Keywords}

China, The NOCs, Energy Revolution, Oil Security, Hedging Mechanism

\section{Introduction}

China's economic development requires a growing oil supply. As shown in Figure 1, the share of oil in Chinese primary energy consumption is between 16 per cent and 22 per cent in the past 20 years. Meanwhile, the domestic oil supply-demand gap is gradually widening as the domestic oil supply has remained basically stable and unchanged while the oil demand has been rising sharply (see Figure 2). As a result, China has to continuously increase its oil imports. According to Figure 3, China's net oil imports continue to grow rapidly in recent years, which results in high oil import dependency and ultimately challenges China's oil security. Specifically, the oil import dependency ratio of China has been higher than 70 per cent since 2018 and will continue climbing in the years to come (China Energy Net, 2021). China's annual crude oil imports in 2019 increased to an average of 10.1 million barrels per day (b/d), an increase of 0.9 million b/d from the 2018 average (EIA, 2020). According to International Energy Agency (IEA), China becomes a net oil importer in 1993, remains the world's top crude oil importer, surpassing the United States in 2017, and it is also the world's largest oil consumer (World Energy Outlook, 2018). Furthermore, China's industrialization and urbanization will continue to accelerate, and the energy demand will increase accordingly. Thus, the energy supply and security will confront tougher challenges (GOV.CN, 2012). In sum, China is highly vulnerable to oil disruptions, and its leaders have always had a strong awareness of oil security and give high priority to ensuring oil security in its national development strategies and policies.

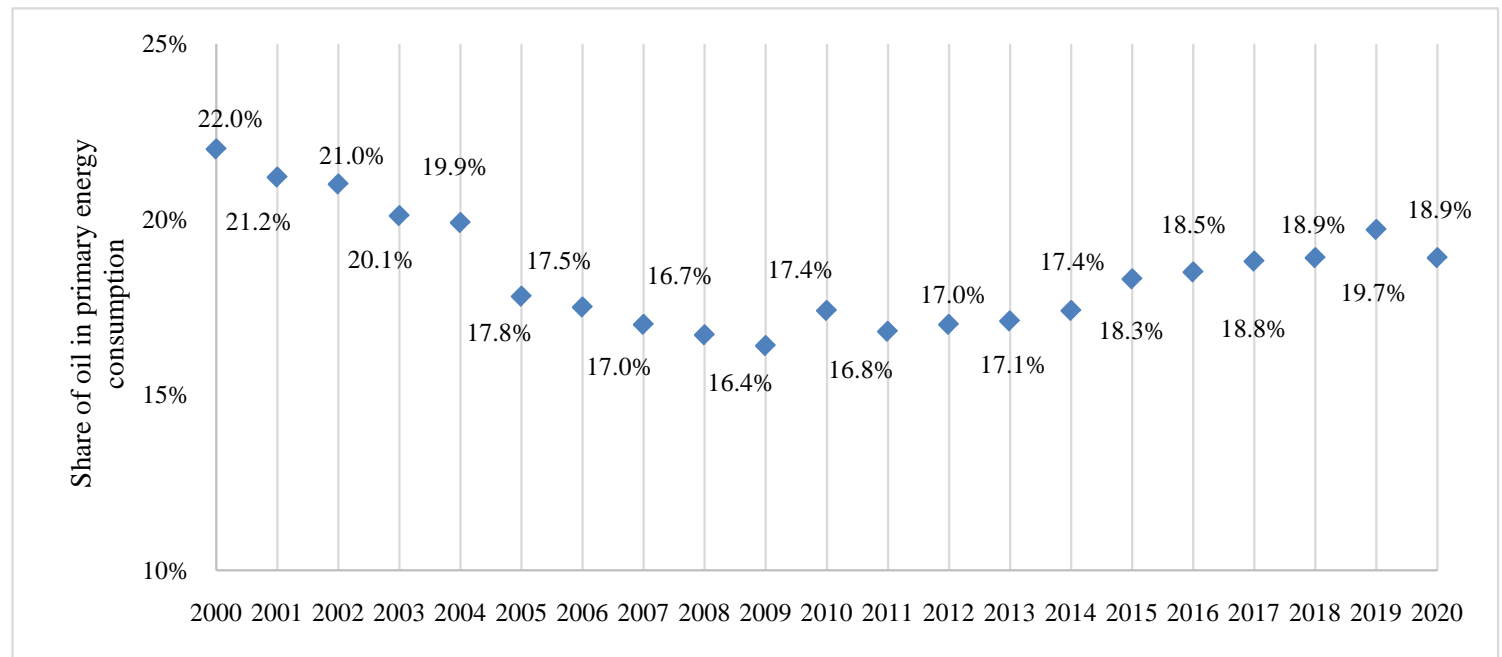

Figure 1. The share of oil in primary energy consumption in China (2000-2020). Source: National Bureau of Statistics (NBS). 


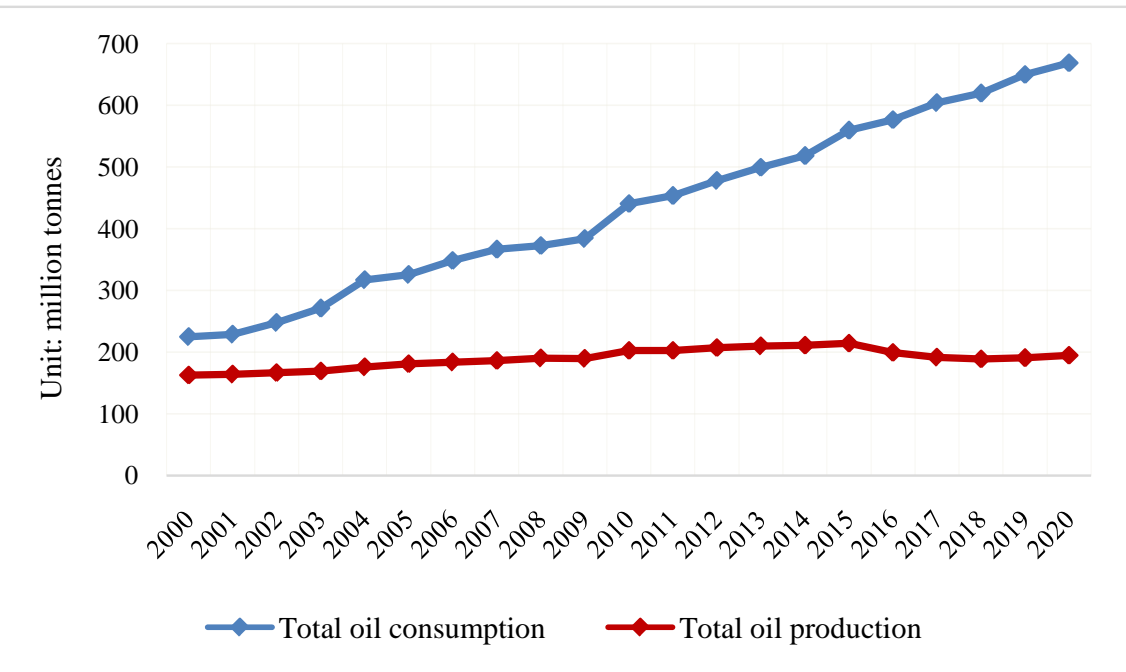

Figure 2. China's growing domestic oil supply-demand gap (2000-2020). Source: NBS.

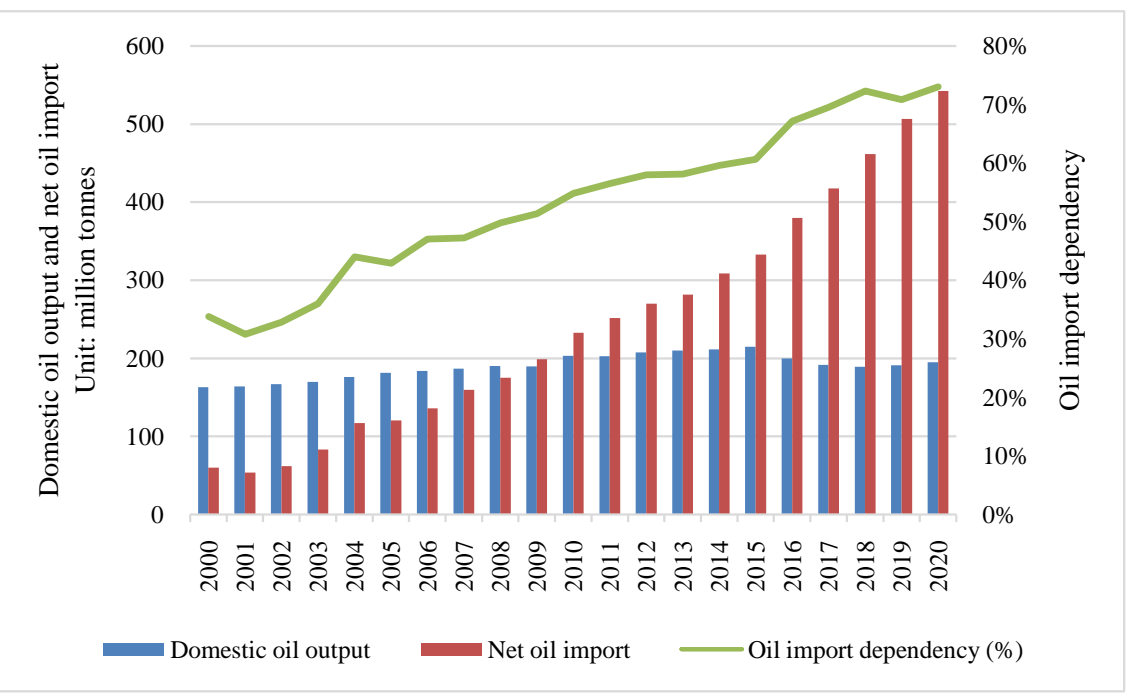

Figure 3. China's oil import dependency (2000-2020). Source: NBS.

So far, China has relied on its major national oil companies (NOCs) to ensure a stable and sufficient oil supply which mainly includes enhancing domestic oil production and overseas oil exploration (Liao, 2015). There are three leading NOCs in China: China National Petroleum Corporation (CNPC), China Petroleum and Chemical Corporation (Sinopec) and China National Offshore Oil Corporation (CNOOC). Born in government reforms and rooted in the Chinese Communist Party (CCP), the NOCs are both state-owned domestic monopolies and autonomous economic actors. They are at the forefront of expanding oil exploration and production (E\&P) at home and abroad and are the core instruments for Beijing to ensure its national oil security.

In 2014, Chinese President Xi Jinping called for an "Energy Revolution", aiming to reduce energy consumption, increase energy supply, improve energy technology and promote institutional reform (IEA, 2017). The revolution of 
energy production and consumption and the transition to a cleaner energy system is driven by the need to tackle climate change, improve air quality and eventually reduce the dependency on fossil fuels (Chen et al., 2019). In September 2020, at the general debates of the 75th United Nations General Assembly, President Xi pledged that China would scale up its Intended Nationally Determined Contributions (INDC) by adopting more vigorous policies and measures, striving to achieve the ambitious targets of carbon peak by 2030 and carbon neutrality by 2060 (XinhuaNet, 2020). It is China's first official announcement of its commitment to carbon neutrality. In this light, the energy sectors and the NOCs in China have to face the accelerated energy transition and adjust their development strategies accordingly.

This paper will be structured in five sections. After the background introduction in the first section, the second part mainly explains the government and the NOCs, and their roles in ensuring China's oil supply. Section three sheds light on the geopolitical risks and oil price volatility to China's oil security, and the hedging mechanism for oil security which is illustrated from three dimensions: domestic and global dimension, continental and maritime dimension, and wartime and peacetime dimension. Section four unpacks China's energy revolution, the mitigation to geopolitical risks, and the changes in the hedging mechanism for oil security due to the buildup of the oil reserves, the development of domestic oil output and the drop in overseas oil investments. The paper ends up with concluding remarks.

\section{Government and the NOCs: The Main Actors to Ensure National Oil Security}

\subsection{A Brief Review of the Relationship between the Government and the NOCs}

Regarding the relationship between the government and its NOCs, the extant literature, by and large, falls into three groups. The first group studies the government's control over the NOCs and the NOCs' compliance with the government. For example, Francisco argues that the major NOCs remain under the authority of the CCP through institutional mechanisms and administrative mobility of the NOCs' senior executives (Francisco, 2013). Liao (2015) examines the relationship between the Chinese government and the NOCs via the lens of the principal-agent theory and she concludes that the government is not always the principal and the NOCs remain a political influence on China's energy policy-making process. The second group highlights the autonomous economic attribute of the NOCs. Among them, some scholars point out that the NOCs have acquired operational autonomy and they could exert influences on energy policy formulation indirectly and potentially through their advisory and technology capacity (Monique, 2012). Amineh and Yang (2014) demonstrate that the NOCs must maintain a balance between the corporate interests, on the one hand, and commitments to party-state interests, on the other. The third body of 
literature has centred on the government-NOCs interactions. Tunsjø believes that the NOCs are largely autonomous and competitive actors, and pursue profits both at home and abroad, while the government pursues strategic security. He further underscores that the NOCs' corporate interests cannot undermine the government's objective of ensuring energy security, and the government has the authority to instruct and control the NOCs during any crisis that might threaten China's oil supply (Tunsjø, 2013). Moreover, the government exploits political and financial tools to assist the NOCs to expand oil investments abroad while the NOCs seek greater autonomy from the government domestically (Downs, 2006; Downs \& Meidan, 2012). Based on these, this research holds the assertion that there are interactions between the government, focusing on strategic security, and the NOCs, pursuing corporate profits as autonomous economic actors, that contributes to China's oil security.

\subsection{The Role of the Government: Control and Support}

The three NOCs remain under the authority of the government due to the institutional framework, as shown in Figure 4, and the Central Organization Department (COD)'s domination of the personnel appointment and mobility of the NOCs. On the one hand, the three NOCs grew out of the government ministries and were set up as state-owned companies in the 1980s. They inherited both staff and the organizational culture from the former Ministry of Petroleum Industry (MPI). All the three leading NOCs are vice-ministerial level companies and the general manager holds the rank of vice-minister (Tunsjø, 2013). Hence, the establishment origin and development background of the NOCs make them deeply rooted in the political system and dominated by the central government. On the other hand, the CCP controls the NOCs through the appointment of personnel. Based on the nomenklatura system and the principle of "the party controls cadres", the COD has the power to appoint and dismiss personnel within the CCP, including the nomination of the chairman and the general manager of the NOCs. That is, the CNPC, Sinopec and CNOOC fall under the nomenklatura system. Because of this, the chairman and the general manager of the NOCs need to balance the interests between the corporate and the CCP as they are evaluated not only on how well they manage their companies, but also on how well they serve the CCP (Downs, 2008; Liao, 2015).

At the same time, the central government assists the NOCs in overseas oil exploration and investments through financial and diplomatic support. China provides large amounts of finance to the NOCs' foreign investments through its two policy banks China Development Bank (CDB) and China Export and Import Bank (CHEXIM) which constitute the backbone of China's global energy finance (Kong \& Gallagher, 2017). Financial support primarily in two forms: loans for Chinese outward foreign direct investment (OFDI) and cross-border mergers and acquisitions (M\&A) in the global energy industry (Gallagher \& Irwin, 2014; Kong \& Gallagher, 2017). The CDB and CHEXIM especially give priority to 


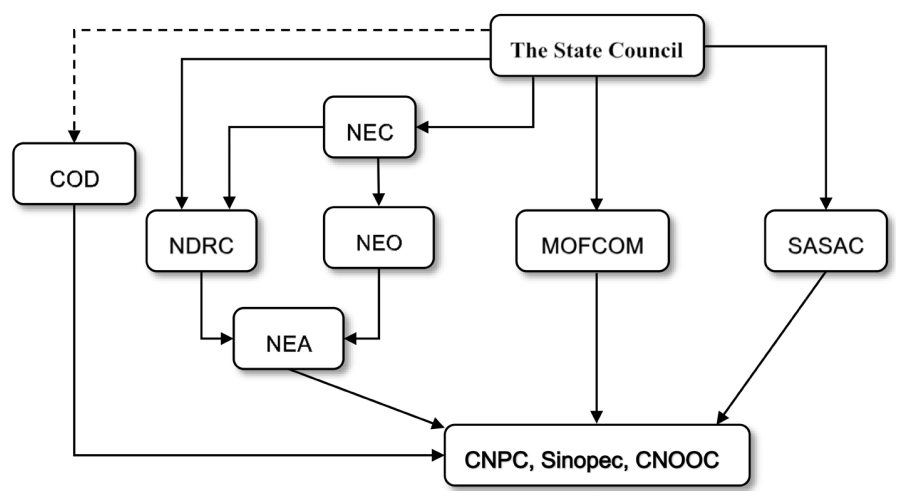

Figure 4. The fragmented organizational structure of China's energy sector. Note: NEC: National Energy Commission. NEO: National Energy Office. NEA: National Energy Administration. NDRC: National Development and Reform Commission. COD: Central Organization Department. MOFCOM: Ministry of Commerce. SASAC: State-owned Assets Supervision and Administration Commission. Source: Adapted by the author from Wu (2013).

funding the NOCs' overseas M\&A projects and energy development programs that can make up for the shortage of domestic resources (Kong, 2019). Over 70 per cent of China's total energy financial support of $\$ 225$ billion, provided by the twin policy banks, has been used to support the NOCs' fossil fuels projects between 2000 and 2017 (Kong, 2019). Just as Patey puts it, loans from Chinese policy banks did help kick-start the international expansion of the Chinese NOCs and equipped them with a competitive advantage in acquiring overseas oil and gas assets (Patey, 2014).

The central government, especially the Ministry of Foreign Affairs (MOFA), plays important role in supporting the NOCs' overseas oil exploration and investments. The synchronization between diplomacy and the pursuit of oil interests abroad has become one of the most salient features of China's foreign policy, and thus China's support for its NOCs through diplomatic channels has been referred to as "petroleum diplomacy" (Kong, 2010). The political leaders conduct high-level official visits to oil-rich countries to secure the NOCs' investment opportunities in those countries, accompanied by foreign aid, infrastructure-for-oil loans, or even military transfer. Andrews-Speed and Dannreuther (2013) point out that almost all the major oil deals that the NOCs have acquired entailed explicit support from the central government through the latter's direct negotiations with the host governments. Moreover, the NOCs generally relied on government-to-government ties to smooth out political risks in their oil host countries, especially in states like Iran, Sudan, and Venezuela (Wolfe \& Tessman, 2012; Patey, 2014).

\subsection{The Role of the NOCs: Policy-Making Engagement and Economic Interest Pursuit}

The NOCs influence policy-making to safeguard their interests, like to obtain investment approval and to strive for more financial support. These policy en- 
gagements or interventions are mainly implemented through the existing institutional designs. First of all, the NOCs dominate the oil-related expertise, technologies and market policies as the NOCs originated from the MPI and inherited some of the MPI's duties and administrative functions. For instance, the CNPC was granted the right to devise oil quality standards and formulate oil market policies. In addition, the chairman and general manager of the NOCs are representatives of the "Two Sessions" (the National People's Congress, NPC; the National Committee of the Chinese People's Political Consultative Conference, NCCPPCC), and they participate in the energy panel discussion and promote policy formulation through the submission of the proposals during the "Two Session" period. Lastly, the personnel fluidity between the bureaucrat system and the NOCs, including the fluidity of the NOCs' executives to the bureaucrat system, and vice versa, as shown in Table 1, provides informal channels for the NOCs to influence the central government's policy-making. In this way, the personnel movements create informal connections between the NOCs and the central government at various levels which sometimes offer NOCs direct access to the country's top leadership to seek critical endorsements for projects promoted by them (Kong, 2010). When an overseas energy investment of Sinopec was refused through formal government procedures, the informal channels were the more efficient avenue of gaining government approval (Jakobson \& Knox, 2010).

While the NOCs are state-owned, they are not government-run. The NOCs are largely independent and their actions appear mainly to be driven by commercial incentives to seek opportunities in the global energy market (OECD/IEA, 2015). In 2020, the Sinopec and the CNPC ranked second and fourth respectively on the Global 500 revenue list, followed by the CNOOC ranking 64th (Fortune Global 500, 2020). As profit-seeking actors, the NOCs hunt oil globally and even invest proactively in high political risk areas where the government does not recommend the investment. Chinese oil companies operate autonomously and direct their considerable investment toward unstable oil-rich states, and they seek international experience in countries offering less competition (Wolfe \& Tessman, 2012). Moreover, the NOCs pursue technical expertise which is one of the differences between the NOCs and the government, as the government does not need oil technology while the oil companies concern new oil technologies and expertise. There is no difference between the three NOCs and international oil corporations in conducting M\&A, joining E\&P projects, and acquiring shares in oil-rich countries.

In a nutshell, the central government and the NOCs are the main actors to guarantee China's oil security while the former, focusing on strategic oil development and oil security, retains political authority over the NOCs and supports the NOCs' overseas oil exploration and investments by diplomacy and finance, and the latter, pursuing corporate profits as autonomous economic actors, engage in energy policy-making and promote overseas oil development. 
Table 1. The personnel fluidity between the NOCs and the government in China.

\begin{tabular}{|c|c|}
\hline Name & Corporate Position \& Bureaucratic Position \\
\hline \multirow{2}{*}{ Wang Tao } & Minister of the Petroleum Industry (1985-1988); \\
\hline & General Manager \& Party Secretary of CNPC (1989-1996) \\
\hline \multirow{4}{*}{ Jiang Jiemin } & Deputy Governor and Deputy Party Secretary of Qinghai Province (2003-2004); \\
\hline & General Manager \& Party Secretary of CNPC (2006-2011); \\
\hline & Chairman \& Party Secretary of CNPC (2011-2013); \\
\hline & Director \& Deputy Party Secretary of the SASAC (2013) \\
\hline \multirow{7}{*}{ Zhou Yongkang } & Deputy Minister of the Petroleum Industry (1985-1988); \\
\hline & Deputy General Manager \& Deputy Party Secretary of CNPC (1988-1996); \\
\hline & General Manager \& Party Secretary of CNPC (1996-1998); \\
\hline & Minister \& Party Secretary of Land and Resources (1998-1999); \\
\hline & Secretary of Sichuan Provincial Party Committee (1999-2002); \\
\hline & Member of the 15th, 16th, 17th Central Committee of the CCP; \\
\hline & State Councilor since 2003 \\
\hline \multirow{3}{*}{ Ma Fucai } & General Manager \& Party Secretary of CNPC (1998-2004); \\
\hline & Deputy Director of the Office of National Energy Leading Group (2005-2008); \\
\hline & Alternate Member of the 16th Central Committee of the CCP \\
\hline \multirow{5}{*}{ Zhang Jianhua } & General Manager \& Deputy Party Secretary of CNPC (2016-2018); \\
\hline & Member of the Party Committee of the NDRC (2018-); \\
\hline & Director \& Party Secretary of the NEA (2018-); \\
\hline & Representative of the 19th CCP National Congress; \\
\hline & Member of the 19th CCP Central Committee for Discipline Inspection \\
\hline \multirow{2}{*}{ Fu Chengyu } & Chairman \& Party Secretary of Sinopec (2011-2015); \\
\hline & Member of the Central Commission for Discipline Inspection (2007-2011) \\
\hline \multirow{3}{*}{ Su Shulin } & Director of CCP Organization Department of Liaoning Province (2006-2007); \\
\hline & General Manager \& Party Secretary of Sinopec (2007-2011); \\
\hline & Acting Governor \& Deputy Party Secretary of Fujian Province (2011-2015) \\
\hline \multirow{2}{*}{ Qin Wencai } & Deputy Minister of the Oil Industry (1979-1982); \\
\hline & General Manager of CNOOC (1982-1985); \\
\hline \multirow{2}{*}{ Wei Liucheng } & General Manager \& Party Secretary of CNOOC (1998-2003); \\
\hline & Acting Governor \& Deputy Party Secretary of Hainan Province (2003-2004) \\
\hline
\end{tabular}

Note: Corporate Position is marked in italics.

\section{Risks to Oil Security and the Hedging Mechanism}

Energy security is "the availability of sufficient energy supplies at affordable prices" (Yergin, 2006) or "the reliable and affordable supply of energy" (Deutch et al., 2006). Some scholars, like Barry Barton, also regard uninterrupted access as a critical feature of energy security (Barton et al., 2004). Accordingly, oil security in this research could be defined as the reliable and uninterrupted oil supply to a country's economy at reasonable prices (Glaser, 2013; Sullivan, 2013). As stressed before, China has high oil import dependency and oil vulnerability. "China is highly vulnerable to energy disruptions; its leaders explain their energy 
policies as a response to this vulnerability" (Lind \& Press, 2018). China's oil strategy reflects a sense of oil vulnerability and the government's distrust of international oil markets (International Crisis Group, 2008). In other words, China is always vigilant about the global oil system dominated by western importing states and highly influenced by unstable exporting countries in the Middle East. These provide explanations for the three NOCs' thirst for overseas oil investments including oil E\&P, and their acquisition of equity oil, as well as the central government's series of energy strategies from "going out" strategy to the Belt and Road Initiative (BRI) to promote oil development.

\subsection{Main Risks to Oil Security}

\subsubsection{Geopolitical Risks}

As a strategic resource, crude oil is unevenly distributed globally. And thus, the mismatch between oil production and consumption worldwide makes geopolitics a significant factor in oil security. Several studies have been conducted to analyze the causal relationship between the geopolitical risks and oil security, and the arguments that "geopolitical risks influence international oil market and oil prices" (Miao et al., 2017; Bouoiyour et al., 2019) and "geopolitical risks disrupt oil supply" (Correlje \& Van der Linde, 2006; Medlock, 2015; Bompard et al., 2017) have been confirmed. As a state with high oil import dependency, China import crude oil from the Middle East, Africa and Latin America which accounted for $46 \%, 14 \%$ and $13 \%$ of its total imports respectively in 2020 (BP, 2021), and this Middle East-Africa-Latin America import portfolio is stable for many years (Wang et al., 2018). However, those crude oil-rich regions mentioned above produce frequent geopolitical risks, which may cause supply disruptions for oil importers like China (Vivoda, 2009).

Geopolitical risk challenges global crude oil security in general and poses a greater threat to China in particular, considering China's growing oil demand and its military force's lack of comprehensive protection for its overseas oil interests (Wang et al., 2021). Furthermore, the U.S. navy's dominant force in the Persian Gulf and the Strait of Malacca further threatens China's oil security as it is heavily dependent on sea lanes. Lastly, piracy, terrorism, military conflicts and other geopolitical incidents also negatively affect oil transportation (Bouoiyour et al., 2019). That is, the geopolitical risks challenge China's maritime oil transport and oil supply.

\subsubsection{Oil Price Volatility}

As oil security refers to the availability of sufficient oil supplies at affordable prices, the oil price is one of the main factors affecting oil security. Financial investments, political games among great powers, geopolitics, emergencies such as the outbreak of the COVID-19 pandemic, and market supply-demand all exert influence over the international oil prices. As China has a high oil import dependency, it is sensitive and vulnerable to the changes in the oil price, and the high crude oil price in the global market would destabilize the Chinese economy 
and society (Li \& Leung, 2011). Notably, the oil price volatility brings two-edged effects on China's oil security: on the one hand, high oil prices promote upstream investment globally but frustrate the oil industrial chains like refining, and thus negatively influence national oil security and destabilize the economic and social development; on the other hand, low oil prices are conducive to the economy and society, but disappoint the domestic and foreign oil investors and dampen the incentive of oil producers to supply oil adequately and reliably which may negatively influence oil security in the long run (Li \& Leung, 2011; Wang et al., 2021). In sum, the impacts of oil prices fluctuation and high oil prices on China's oil security are complex due to their opposite effects on oil investment and economic development.

\subsection{The Hedging Mechanism for Oil Security}

Generally, hedging refers to "an insurance policy against opportunism" (Lake, 1996). In the traditional balance of power theory, hedging is located between balancing and bandwagoning ("balancing-bandwagoning" spectrum) as the state's third strategic choice (Murphy, 2010; Lim \& Cooper, 2015; Koga, 2018). Kuik defines hedging as a behaviour in which a state seeks to offset risks by pursuing multiple policy options that are expected to produce mutually counteracting effects under the situation of high uncertainties and stakes (Kuik, 2008). In other words, a state's hedging behavior could be clarified as one that seeks to reduce, avoid or offset risks and uncertainties, or to reconcile confrontation. More specifically, through hedging, a state conducts a counteracting policy, with economic cooperation, diplomacy and military confrontation, to manage potential risks.

The existing literature analyzes China's hedging strategy for oil security from the perspective of the second-tier state's insurance behavior to cope with uncertainties in a unipolar system, and from the perspective of risk management, which is based on the interactions between the government and the NOCs, to avoid potential risks. For example, Tessman and Wolfe (2011) develop a structural theory of interstate competition to explain the second-tier states' foreign policy behaviors in a unipolar system. They believe that the global energy access is a zero-sum game between the major powers, and a four-step identification mechanism is designed to distinguish the strategic hedging behavior which includes: improve its competitive ability to address a militarized dispute with the system leader or to compensate for the potential loss of public goods that are currently provided by the system leader; not hard balancing; concern the major national security issues; the observable cost involved (Tessman \& Wolfe, 2011). In this light, China's hedging behaviors for oil security involve increasing and diversifying overseas oil investments, building transnational pipelines, strengthening strategic petroleum reserves (SPR) and engaging in oil diplomacy (Downs, 2004). In addition, Tunsjø (2013) argues that hedging is a typical feature of China's energy security policy which captures the interactions between 
the government, pursuing strategic security, and the NOCs, searching for market profits. By combining security and profit considerations, Tunsjø links hedging to risk management and identifies the domestic, global, maritime, and continental aspects of China's energy security policy (Tunsjø, 2013). This hedging framework confirms that China adapts to its increasing oil import dependency by reducing its exposure to potential supply disruption risks and sudden price rises.

The key to the hedging mechanism is to provide alternatives to the potential risks. Drawing on insights from the discussion above, this study illustrates China's hedging mechanism for oil security from three dimensions: domestic and global dimension, continental and maritime dimension, and wartime and peacetime dimension. Based on the interactions between the government and the NOCs, the hedging mechanism for China's oil security could be illustrated as in Diagram 1.

To be specific, in normal times, the NOCs pursue market profits by oil E\&P at home and abroad, especially through overseas direct investment and M\&A. In this process, the central government provides financial and diplomatic support for the NOCs' oil expanding activities. In this case, the profits pursuit behavior of the NOCs not only brings market benefits for the oil companies, but also increases and diversifies China's oil supply. Meanwhile, it is demonstrated that China's overseas oil investments contribute to China's oil import both through the increase of oil import volume and the diversification of import sources, and thus enhancing China's oil security (Zheng, 2017; Duan et al., 2018; Shi \& Cai, 2020; Zhao et al., 2020). Notably, in normal times, most of the NOCs' overseas equity oil and crude oil production will not be shipped back to China. For example, in 2007, more than half of the overseas oil produced by the Chinese NOCs is sold outside China (Downs, 2010). According to Chinese Energy Policy 2012, 90 per cent of the energy resources that Chinese NOCs invests abroad are sold locally (GOV.CN, 2012). However, during the oil crisis period like sudden supply interruption or sudden rising of oil price on the international oil market, the Chinese government will strengthen its control over the NOCs, encourage the NOCs to increase domestic oil production and require the NOCs to ship the oil produced overseas back to China. The NOCs will follow the directives from the central government and put the national oil security above the corporate profits in the case of emergencies. The National Development and Reform Commission (NDRC) declaimed that, when China's energy security was concerned, it preferred oil and gas to be acquired by the NOCs from the wellhead through overseas investments rather than bought from the international oil market (Jakobson \& Knox, 2010).

Domestically, SPR is an essential protection measure to reduce the impact of oil supply shocks and ensure a state's economic development when faced with oil supply crises. For instance, the IEA recommends its member countries store at least 90 days of net imports in case of potential oil interruption. China has also developed its SPR as the central part of its domestic hedging strategy to ensure against oil supply disruptions and price volatility, thereby maintaining its 


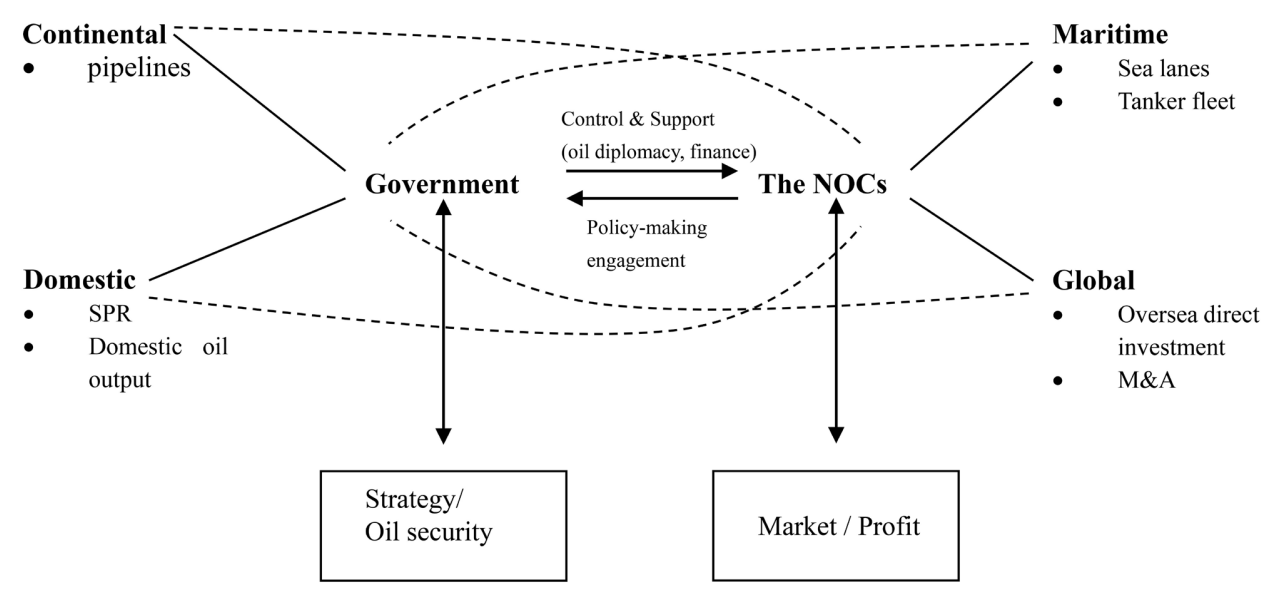

Diagram 1. China's hedging mechanism for oil security.

domestic stability and economic growth (Tunsjø, 2013). Also, the promotion of domestic crude oil output is conducive to improving oil self-sufficiency and reducing the oil import dependency, thus strengthening China's oil security.

Regarding sea lanes and continental pipelines, China relies heavily on seaborne oil supply which has high vulnerability when considering the geopolitics risks and China's lack of a navy to protect its sea lines of communications (SLOCs). In wartime or crisis, especially with blockade of seaborne oil imports or oil supply disruptions caused by conflicts in oil-rich regions, China would hedge against such risks by relying on its domestic oil output, SPR and the pipelines to ensure domestic oil supply and minimize oil transportation risks. Especially, the development of continental pipelines is an insurance strategy to hedge against the oil supply disruptions in the sea lanes. At present, China has three cross-border oil pipelines in its northwest, northeast, southwest, that is, the Kazakhstan-China oil pipeline, the Russia-China oil pipeline and the Myanmar-China oil pipeline (see Table 2). Policy-makers and researchers believe that pipeline oil transportation bypasses high-risk routes such as the Malacca Strait (Erickson \& Collins, 2010) and is an alternative to seaborne oil supplies during a wartime contingency or blockade.

In sum, China's hedging mechanism for oil supply shows how the NOCs' pursuit of market profits in peacetime also provides a hedge against oil supply interruptions and high crude prices that might threaten China's oil security in periods of crisis, how the SPR and domestic oil output provide a short-term hedge against turbulence and uncertainty in the international oil market, and finally how the continental pipelines act as a hedge if the seaborne oil shipments are disrupted during a wartime contingency or blockade.

\section{Changes in Risks and Hedging Mechanism Caused by the Energy Revolution}

\subsection{Energy Revolution in China}

In June 2014, President Xi Jinping put forward the new strategic thinking of 
energy security to promote energy revolution in consumption, supply, technology and institution, and comprehensively strengthen international energy cooperation (XinhuaNet, 2014). To be specific, in terms of oil development, the energy revolution proposed to pragmatically advance overseas oil cooperation, improve oil E\&P at home and abroad, increase oil SPR, strengthen the construction of oil pipelines and storage facilities, and improve the energy emergency system. Subsequently, a series of policies were issued to ensure the advancement and implementation of its energy revolution (see Table 3). For example, the Energy Development Strategy Action Plan (2014-2020) and the Energy Production and Consumption Revolution Strategy (2016-2030), reemphasizes that China should increase domestic oil E\&P, stabilize domestic oil supply, accelerate the construction of oil reserve bases, and ensure a diversified and stable source of overseas oil supply, thereby ensuring its oil security (NEA, 2014; NDRC, 2017). Furthermore, these policies mainly focus on the sustained growth in the utilization of renewables, consumption decrease in fossil fuels and clarify the strategic goals and specific measures of the energy revolution. They also set the targets for 2030 and 2050 (see Table 4), for example, non-fossil fuel in the energy mix should be higher than 20 per cent in 2030 and above 50 per cent in 2050 .

Table 2. China's cross-border oil pipelines and sea lanes.

\begin{tabular}{ccccc}
\hline Origin of pipeline & Name & Capacity/year & Length & Operation time \\
\hline Kazakhstan & Kazakhstan-China oil pipeline & 20 million tons & $2798 \mathrm{~km}$ & 2009 \\
\hline Myanmar & Myanmar-China oil pipeline & 22 million tons & $771 \mathrm{~km}$ & 2017 \\
Russia & Russia-China oil pipeline & 15 million tons & $999.04 \mathrm{~km}$ & 2011 \\
& & 15 million tons & $941.8 \mathrm{~km}$ & 2018 \\
\hline Sea lanes & Malacca Strait; Pacific & & &
\end{tabular}

Table 3. Overview of the major policies concerning energy revolution in China.

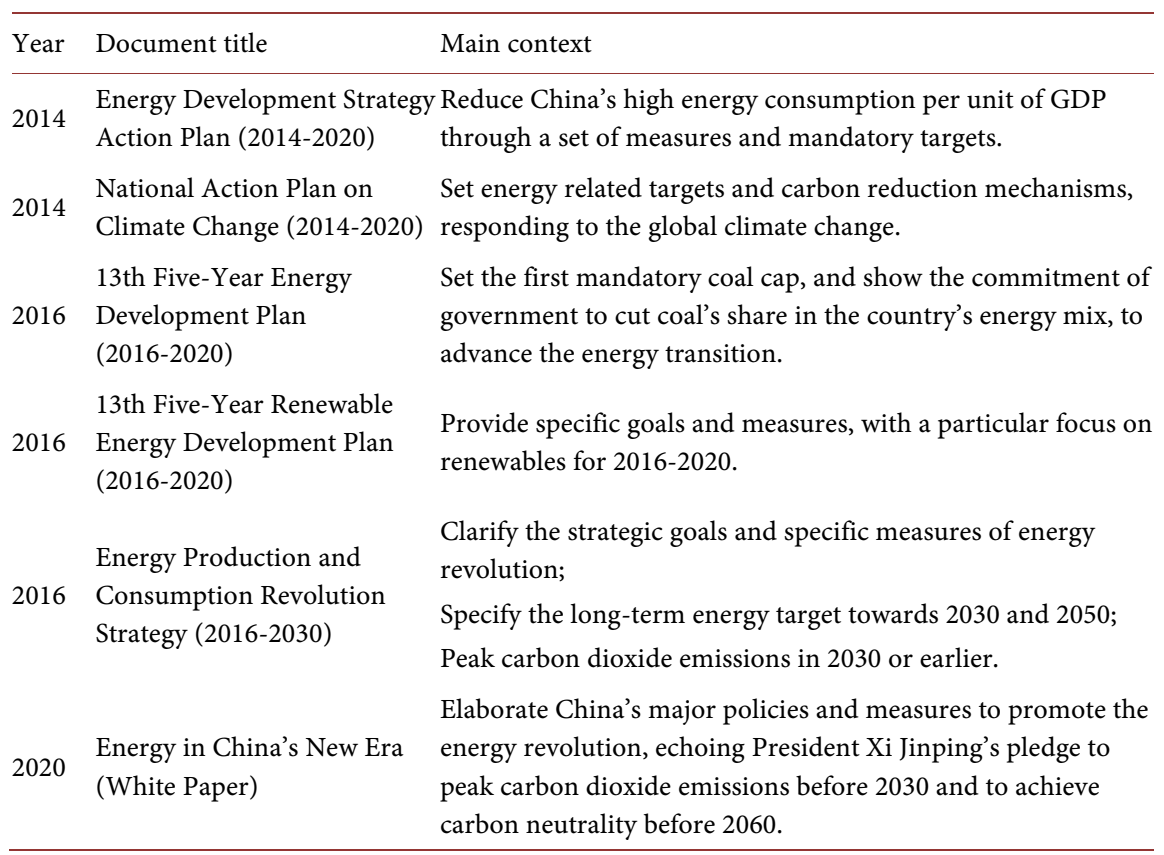


Table 4. Targets within China's energy revolution.

\begin{tabular}{|c|c|c|c|c|}
\hline & Target & 2020 & 2030 & 2050 \\
\hline $\begin{array}{l}\text { Energy } \\
\text { consumption }\end{array}$ & Total energy consumption & $\begin{array}{l}5 \text { billion tons of } \\
\text { standard coal }\end{array}$ & $\begin{array}{l}6 \text { billion tons of } \\
\text { standard coal }\end{array}$ & $\begin{array}{l}\text { fshould be } \\
\text { stable }\end{array}$ \\
\hline \multirow{2}{*}{$\begin{array}{l}\text { Energy } \\
\text { efficiency }\end{array}$} & $\begin{array}{l}\text { Energy consumption per unit of GDP } \\
\text { (compared with 2015) }\end{array}$ & $-15 \%$ & \multicolumn{2}{|l|}{$\begin{array}{l}\text { reach the world } \\
\text { average }\end{array}$} \\
\hline & $\begin{array}{l}\text { Primary energy consumption } \\
\text { (unit: billion tonne tce) }\end{array}$ & $5 \%$ & \multicolumn{2}{|l|}{$6 \%$} \\
\hline \multirow[t]{2}{*}{$\begin{array}{l}\text { Energy } \\
\text { self-sufficiency }\end{array}$} & Energy self-sufficiency rate & above $80 \%$ & & \\
\hline & $\mathrm{CO}_{2}$ emission & & \multicolumn{2}{|l|}{ peak or earlier } \\
\hline \multirow{3}{*}{$\begin{array}{l}\text { Carbon } \\
\text { emission }\end{array}$} & $\begin{array}{l}\text { Carbon emission per unit of GDP } \\
\text { (compared with 2015) }\end{array}$ & $-18 \%$ & & \\
\hline & $\begin{array}{l}\text { Carbon emission per unit of GDP } \\
\text { (compared with 2005) }\end{array}$ & $-40 \%-45 \%$ & $-60 \%-65 \%$ & \\
\hline & Non-fossil fuel in the energy mix & $15 \%$ & $20 \%$ & $\begin{array}{l}\text { above } \\
50 \%\end{array}$ \\
\hline \multirow{4}{*}{$\begin{array}{l}\text { Non-fossil } \\
\text { fuel }\end{array}$} & $\begin{array}{l}\text { Non-fossil power generation account } \\
\text { for total power generation }\end{array}$ & & $50 \%$ & \\
\hline & $\begin{array}{l}\text { New energy demand met by clean } \\
\text { energy }\end{array}$ & & $\begin{array}{l}\text { Should mostly } \\
\text { be done }\end{array}$ & \\
\hline & Coal in the energy mix & below 58\% & & \\
\hline & Natural gas in the energy mix & $10 \%$ & $15 \%$ & \\
\hline $\begin{array}{l}\text { Energy } \\
\text { governance }\end{array}$ & \multicolumn{4}{|c|}{$\begin{array}{l}\text { By } 2050 \text {, China shall become an important participant of international energy } \\
\text { governance. }\end{array}$} \\
\hline $\begin{array}{l}\text { Vision } \\
\text { towards } \\
\text { future }\end{array}$ & \multicolumn{4}{|c|}{$\begin{array}{l}\text { By } 2030 \text {, China aims to peak the } \mathrm{CO}_{2} \text { emission. } \\
\text { By } 2050 \text {, the total energy consumption should be stable, with more than half } \\
\text { coming from non-fossil energy. }\end{array}$} \\
\hline
\end{tabular}

Source: made by the author from Energy Development Strategy Action Plan (2014-2020), Energy Production and Consumption Revolution Strategy (2016-2030).

With the advancement of the energy revolution, there is a trend of coordinated development between "conventional oil and unconventional oil", "oil and natural gas", and "fossil energy and renewable energy", driven by the intertwined issues of energy security, economic development and climate change. Hence, the energy revolution not only provides opportunities for further promoting China's oil development through the increase of oil E\&P and the expansion of oil reserves, but also provides a low-carbon development path for the NOCs.

\subsection{The Energy Revolution Alters the Way Energy and Geopolitics Interact}

As mentioned above, the geopolitical risks are threats to energy security. However, the energy revolution alters the way energy and geopolitics interact and redefines the weight of geopolitical risks in energy security. Firstly, although fos- 
sil fuels are distributed unevenly and linked inherently with geopolitics, the global distribution of renewable energy sources is more evenly spread than fossil fuels (Paravantis \& Kontoulis, 2020). Renewable energy is more resistant to geopolitical strife and lessens the negative impacts of geopolitical conflicts on energy security, so as to alleviate the world governments' concerns about the Strait of Hormuz and the political stability in the Middle East. As such, substituting fossil fuels with renewable energy in the energy revolution offers a dual-benefit: the resolution of climate change issues and the ease of energy security worries thanks to the diverse alternative fuel supplies away from fossil fuel-producing countries which result in breaking off the shackles of geopolitics (Wang, 2020). Secondly, the energy revolution makes fundamental changes to the energy mix, and the growing share of renewable energy in the energy mix help reduce the demand for fossil fuels, which may limit a state's energy import dependence through exploiting domestically controllable energy supplies. This is considered the most effective way to minimize energy supply threats (Bang, 2010). Finally, China's energy revolution, together with the trends of energy transition worldwide, is fundamentally changing the way energy is produced and consumed. The share of renewable energy in primary energy consumption has increased both in China and in the globe, and the international oil supply and demand have also been affected accordingly. With the advancement of the energy revolution and the development of renewable energy, it is expected that oil is no longer a strategic resource but a commodity. In this vein, the energy revolution is considered a game changer in geopolitical risks and energy security.

\subsection{Changes in the Hedging Mechanism for Oil Security}

\subsubsection{The Buildup of Oil Reserves}

The requirements that creating a diversified domestic oil supply system and enhancing strategic reserves in energy revolution reflect China's actual conditions that it has high oil import dependency, in combination with a lack of strategic oil reserve capacity, which weakens China's ability to respond to emergencies (Shell International B.V. and DRC, 2020). Hence, optimization of the energy supply system and enhancement of oil security are high on the agenda of the energy revolution. In the Energy Production and Consumption Revolution Strategy (2016-2030), enhancing strategic petroleum reserves and emergency response capabilities are proposed which require the establishment of an oil reserve mechanism that combines government SPR and corporate commercial reserves (NDRC, 2017). China's preliminary work on national SPR began in 1993, approved in 2003 with a planned total reserve capacity of 500 million barrels to be complete by 2020 (Xu \& Chung, 2016), and the construction of the first four SPR sites commenced in 2004 with a capacity of about 103 million barrels (Singh, 2012; Jiao et al., 2014). Actually, there is no publicly released data on China's total oil reserve capacity as it is a tightly guarded state secret, and the exact details of China's commercial oil reserves are not clear, either. However, the relevant 
data concerning China's oil reserves are calculated and published by experts, scholars, consulting agencies and newspapers. As shown in Table 5, by mid-2017, China has built nine national oil reserve bases with 37.73 million tons (about 275 million barrels) of SPR, and at the end of 2020, China's SPR is estimated to grow to between 290 million and 370 million barrels due to the low prices caused by the Covid-19 pandemic (Chen \& Xu, 2020).

In terms of commercial oil reserves, the commercial reserve capacity researched 300 million barrels in 2009, with Sinopec and CNPC accounting for 50 per cent and 40 per cent, respectively (Yu, 2011), and the ratio of SPR to commercial reserve capacity is approximately 1:3. Moreover, there was a further 168 million barrels of commercial reserve capacity by the end of 2010 (Singh, 2012). According to the report issued by the CNPC, as of the end of 2013, China's SPR capacity reached 141 million barrels, equivalent to only 8.9 days of total consumption, and the commercial oil reserve has a capacity of about 13.8 days of total consumption (Sohu News, 2015). After announcing the implementation of the energy revolution in 2014, President Xi Jinping presided over the ninth meeting of the Central Finance and Economics Leading Group and pointed out that speeding up the improvement of the petroleum strategic reserve system (XinhuaNet, 2015). Also, the NDRC issued Guidelines on Strengthening the Operation and Management of Commercial Crude Oil Reserves for Crude Oil Processing Enterprises which highlighted the promotion of commercial oil reserves and the establishment of a minimum commercial oil reserves system, requiring the crude oil enterprises to store no less than 15 days of the average processing volume of crude oil (NDRC, 2015). In 2020, China took the opportunity of the oil price slump to stockpile cheap oil and increase its oil reserves. Wood Mackenzie calculated that China's oil reserve, which includes government SPR and commercial inventories, could reach 1.15 billion barrels in 2020 which hit 90 per cent of China's storage capacity, equivalent to around 83 days of its domestic oil demand and 105 days of net imports (Wood Mackenzie, 2020).

Table 5. Chinese strategic petroleum reserves.

\begin{tabular}{cccccc}
\hline & \multicolumn{2}{c}{ Target } & \multicolumn{3}{c}{ Completion } \\
\cline { 2 - 6 } & Year & Capacity (mb) & Year & Capacity (mb) & Cumulative level (mb) \\
\hline Phase I & 2008 & 103.2 & By 2009 & 103.2 & 103.2 \\
Phase II & 2013 & 206.9 & 2011 & 18.9 & 122.1 \\
& & & 2013 & 18.9 & 141 \\
Phase III & 2020 & 189.9 & June-2016 & 102 & 243 \\
& & & June-2017 & 32 & 275 \\
& & & $*$ End-2020 & $15-95$ & $290-370$ \\
Total SPR & & 500 & & & \\
\hline
\end{tabular}

*: estimates by analysts. Note: The construction of the Phase II was delayed and finished in 2015. Source: updated by the author from Chen and Xu (2020), Xu and Chung (2016). 
Figure 5 shows the share of SPR and commercial oil reserves in China's crude stockpiling mix in 2020. The same as that in 2009, the ratio of SPR to commercial reserve including major commercial and non-major commercial reserves, is also about 1:3. However, the non-NOCs commercial oil reserves have increased significantly compared to that in 2009. Therefore, looking at the data of crude oil reserves before and after China's energy revolution, it can be found that not only the volume of China's oil reserves has increased significantly, but the structure of oil reserves has changed, with an obvious increase in the share of non-major commercial oil reserves.

\subsubsection{The Arduous Development of Domestic Crude Oil Output}

As the development of domestic oil output contributes to reducing oil import dependency, thereby strengthening oil security, the energy revolution proposes to improve the level of large-scale development of unconventional oil and gas and develop oil exploration technologies to further improve domestic oil output. However, China has suffered three consecutive years of decrease in domestic oil output since 2016 (see Figure 6) because the low international oil prices encouraged the NOCs to reduce domestic output and upstream investments and import more oil abroad (Downs, 2019). Faced with this situation, the National Energy Administration (NEA) instructed the NOCs to bolster upstream activities to enhance national oil security in summer 2018. As a result, the three NOCs successively issued their Seven-Year Action Plans (2019-2025) in 2019 and accelerated investments in domestic oil E\&P, aiming to improve the domestic annual oil output to 200 million tonnes by 2025. Ultimately, the crude oil output in 2019 is 191 million tons, a 1.1 per cent increase over the previous year which reversed the continuous domestic oil output decline (Liu \& Jiang, 2020). Despite the low oil prices caused by the Covid-19 pandemic in 2020, China still increased its domestic oil output to 194.9 million barrels, accounting for about 36 per cent of its crude oil import (542 million tonnes), and 4 million tonnes higher than that in 2019.

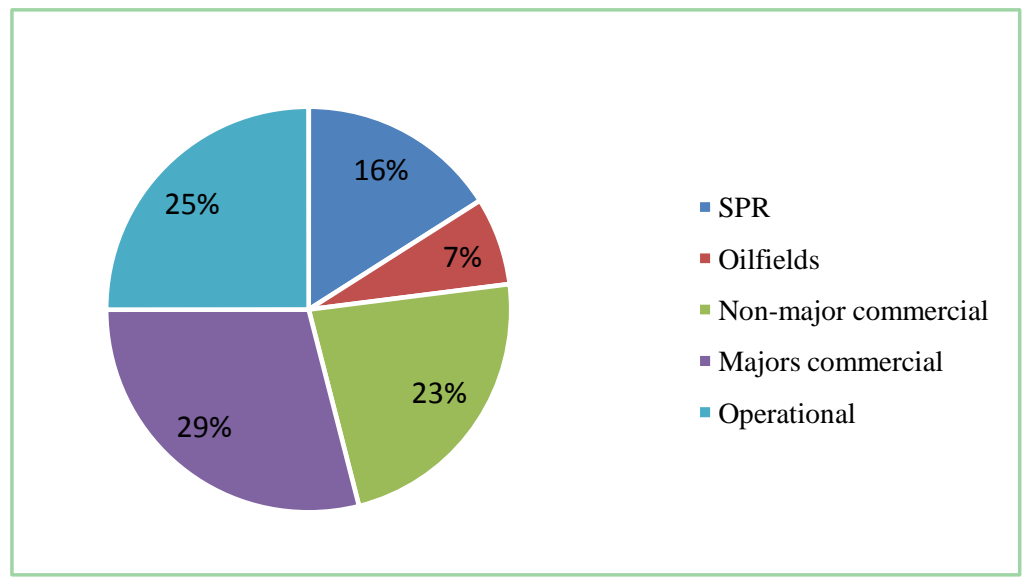

Figure 5. China's crude oil stockpiling mix. Source: Sublime China Information 2020. 


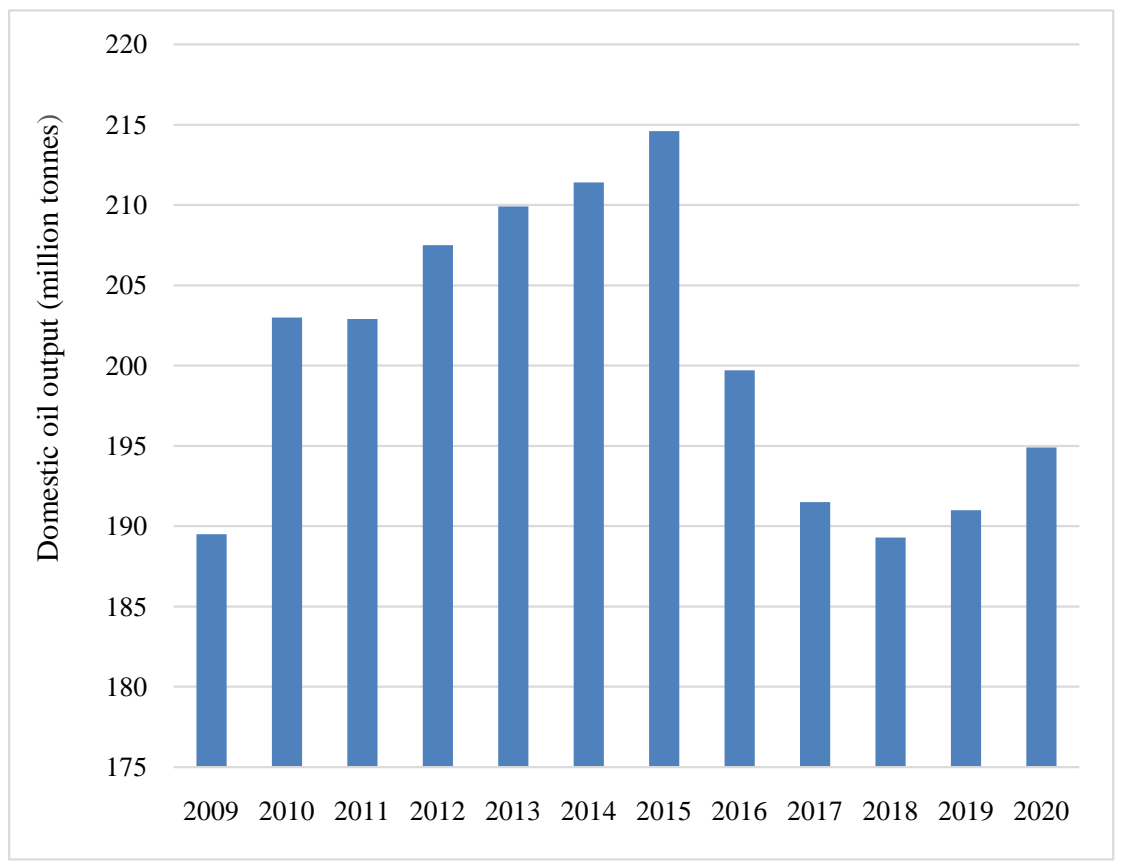

Figure 6. China's domestic crude oil output. Source: NBS.

It should be noted that China's fossil energy endowment is characterized by "more coal, less gas, and lack of oil", which shows the limitations of its oil development (Zhu \& Wang, 2020). The lack of oil resources indicates the difficulties to improve China's domestic crude output. Furthermore, although China's domestic oil output has recovered to grow slowly since 2019, its oil import dependency remains at a relatively high level, above 70 per cent, as shown in Figure 3.

\subsubsection{Downward Trend of Overseas Oil Investments but Rising Foreign Renewables Investments}

China's energy revolution aims to build a clean, low carbon, safe and efficient energy system for the future and the carbon neutrality commitment makes renewable energy high on the investment agenda for future profitability, while the investment in fossil energy becomes less attractive. According to China Global Investment Tracker, Chinese overseas oil investments has shown a downward trend since 2014 and the NOCs' overseas oil investment is consistent with this trend, too (see Figure 7). Meanwhile, China has been the top investor in renewable energy worldwide for nine out of the last ten years (Frankfurt School, 2019). The year 2015 witnessed a total of $\$ 20$ billion foreign renewable investment by Chinese firms, and in 2016, the total foreign renewable investment in deals from Chinese firms reached $\$ 32$ billion, with a 60 per cent year-on-year rise (IEEFA, 2017). China's renewable energy worldwide hit a record of $\$ 143$ billion in 2017, and although there was a slight drop in 2018 and 2019 due to Beijing's policy change in the feed-in tariff, the global low-carbon development trends continue to indicate that investing in renewables is investing in a profitable future (Frankfurt School, 2019). 


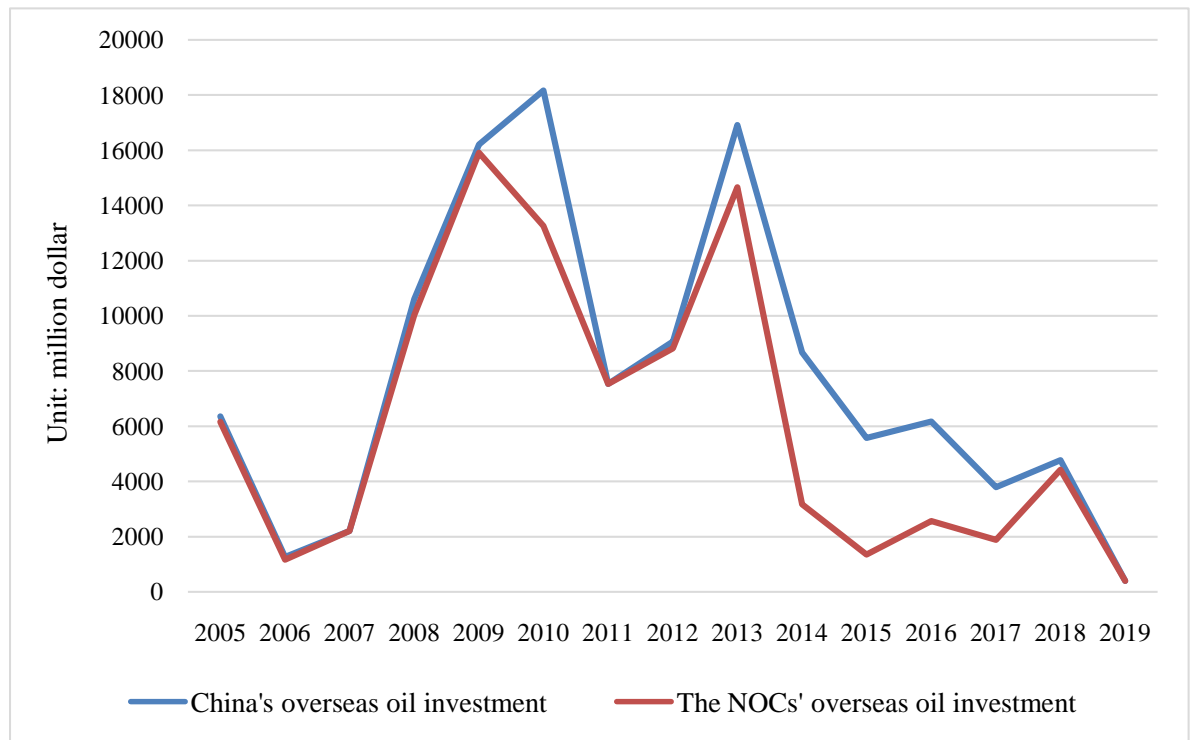

Figure 7. China's overseas oil investment and the NOCs' overseas oil investment. Source: China Global Investment Tracker (accessed on 20 August 2021).

In addition, China is pursuing a renewable energy "going global" strategy, particularly through the BRI to expand its renewable energy development globally. As shown in Figure 8, the share of solar and wind energy investments in the BRI has risen for five consecutive years since 2016, and their share in the BRI energy investment has reached 22.74 per cent in 2020 , compared to the 5.79 per cent in 2013. On the contrary, the share of oil in energy investment along the BRI countries had dropped from 38.09 per cent in 2013 to 13.23 per cent in 2020. In particular, the renewable energy investments (solar, wind, hydro) accounted for 57 per cent of Chinese BRI energy investments in 2020, increasing their share from 38 per cent in 2019, amid a total decrease of BRI investments of 54 per cent (Wang, 2021). In other words, the trend of investment in renewables in the BRI is upward, while the oil investment trend in the BRI energy investments is downward. As China's overseas oil investments contribute to its oil import through the increase of oil import volume and the diversification of import sources, the decline in overseas oil investments may cause concerns about China's oil imports and affect negatively the hedging mechanism for oil security.

In the energy revolution, Beijing's refocus from fossil fuels to renewable energy at home and abroad matches its economic and social development demands: combating climate change, promoting low-carbon sustainable economic development and boosting energy security by reducing reliance on costly fuel imports (Campbell, 2019). Meanwhile, the development of renewables in China and other states in the world, whether it is solar, wind or hydro, has the potential to mitigate geopolitical risks by making China and the world less dependent on conflict or restive oil production regions. Also, the energy revolution triggers changes in the hedging mechanism for China's oil security: the buildup of oil reserves, especially the development of commercial oil reserves; the domestic oil 


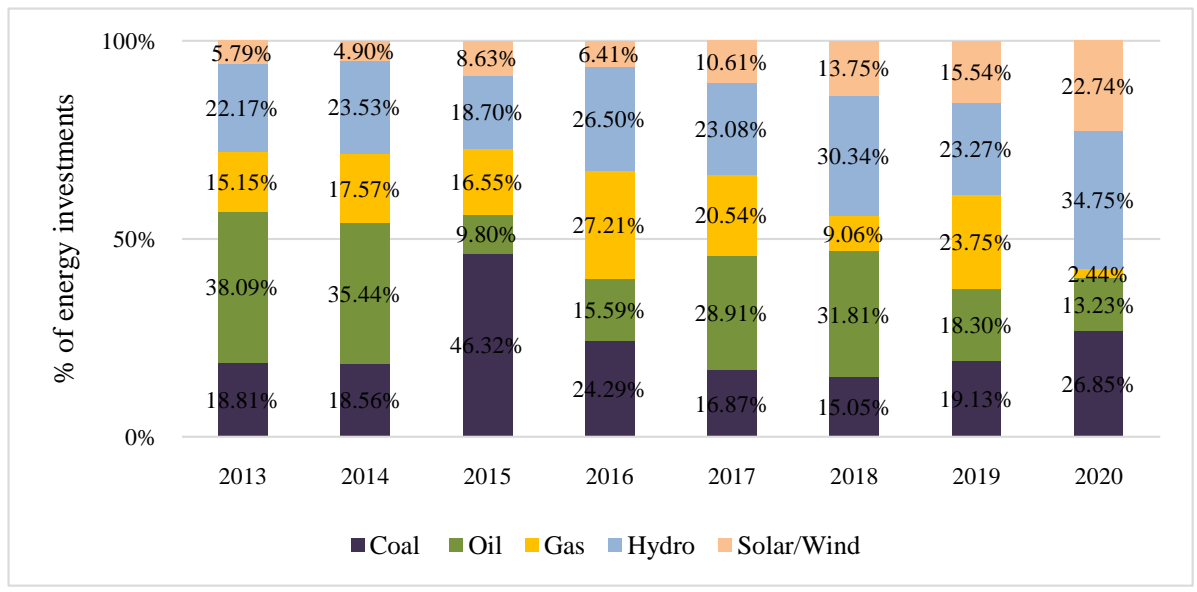

Figure 8. Chinese energy investments in the Belt and Road Initiative (BRI) 2013-2020. Source: 2021 IIGF Green BRI Center.

output, highly valued but arduous advanced; the drop in overseas oil investments but increase in foreign renewables investments. Notably, the buildup of oil reserves and the promotion of domestic oil output contribute to strengthening the hedging mechanism, while the decrease in overseas oil investments weakens the hedging mechanism and thus affects China's oil security negatively. And thus, China's oil security and its capabilities to respond to potential oil supply interruptions have changed accordingly.

\section{Conclusion}

This study analyzes how the energy revolution influences China's oil security by exploring the changes in risks and the hedging mechanism. The energy revolution is driven by the intertwined issues of energy security, economic development and climate change, and one of its major goals is to improve China's energy independence and ensure energy security. In this light, China has to address its high oil import dependency and oil supply vulnerability. The central government and the NOCs are the main actors to guarantee China's oil security while the former, focusing on strategic oil development and oil security, retains political authority over the NOCs and supports the NOCs' overseas oil exploration and investments by diplomacy and finance, and the latter, pursuing corporate profits as autonomous economic actors, engage in energy policy-making and implement overseas oil development. Based on the interactions between the government and the NOCs, the overseas oil investments and the domestic oil production and SPR, together with the maritime oil transportation and continental pipelines, provide alternatives for China's oil supply in general and in wartime in particular, thus forming the hedging mechanism for China's oil security.

The energy revolution alters the way energy and geopolitics interact, and the development of renewables in China and other states in the world mitigates geopolitical risks by making China and the world less dependent on conflict or 
restive oil production regions. Meanwhile, the energy revolution triggers changes in the hedging mechanism for China's oil security due to the buildup of oil reserves including the commercial oil reserves, the development of domestic oil output, and the drop in overseas oil investments but increase in foreign renewables investments. Notably, the buildup of oil reserves and the promotion of domestic oil output contribute to strengthening the hedging mechanism, while the decrease in overseas oil investments weakens the hedging mechanism and thus affects China's oil security negatively.

Although energy transition and the development of renewable energy have attracted unprecedented attention from industry, academia, and policy-makers, oil security still cannot be ignored especially considering its share in primary energy consumption and China's high oil import dependency. In this case, the impacts of renewables' development on fossil energy security are worthy of attention and research. This paper contributes to understanding China's oil security in the context of the energy revolution by analyzing the changes in the hedging mechanism. Further research could include a deeper examination of the impacts of overseas renewable energy investments on China's oil investments, the trends of the NOCs' overseas renewable energy investments and the NOCs' role in the energy revolution, as well as the impacts of energy revolution on the competitiveness of China's oil acquisition in the global energy market.

\section{Conflicts of Interest}

The author declares no conflicts of interest regarding the publication of this paper.

\section{References}

Amineh, M. P., \& Yang, G. (2014). Introduction: Geopolitics of Transnationalization of Chinese National Oil Companies. Perspectives on Global Development and Technology, 13, 495-535. https://doi.org/10.1163/15691497-12341316

Andrews-Speed, P., \& Dannreuther, R. (2013). China, Oil and Global Politics. Routledge.

Bang, G. (2010). Energy Security and Climate Change Concerns: Triggers for Energy Policy Change in the United States? Energy Policy, 38, 1645-1653.

https://doi.org/10.1016/j.enpol.2009.01.045

Barton, B., Redgwell, C., Rønne, A. et al. (2004). Introduction. In B. Barton et al. (Eds.), Energy Security: Managing Risk in a Dynamic Legal and Regulatory Environment (pp. 3-5). Oxford University Press.

Bompard, E., Carpignano, A., Erriquez, M. et al. (2017). National Energy Security Assessment in a Geopolitical Perspective. Energy, 130, 144-154.

https://doi.org/10.1016/j.energy.2017.04.108

Bouoiyour, J., Selmi, R., Hammoudeh, S. et al. (2019). What Are the Categories of Geopolitical Risks That Could Drive Oil Prices Higher? Acts or Threats? Energy Economics, 84, Article ID: 104523. https://doi.org/10.1016/j.eneco.2019.104523

BP (2021). Statistical Review of World Energy.

https://www.bp.com/content/dam/bp/business-sites/en/global/corporate/pdfs/energy-e conomics/statistical-review/bp-stats-review-2021-full-report.pdf 
Campbell, C. (2019). China Is Bankrolling Green Energy Projects around the World. https://time.com/5714267/china-green-energy/

Chen, A. Z., \& Xu, M. Y. (2020). China’s Top Independent Crude Oil Storage Operators, SPR Updates. Reuters. https://www.reuters.com/article/china-oil-storage-idUSL4N2HS1CV

Chen, C., Xue, B., Cai, G. T. et al. (2019). Comparing the Energy Transitions in Germany and China: Synergies and Recommendations. Energy Reports, 5, 1249-1260. https://doi.org/10.1016/j.egyr.2019.08.087

China Energy Net (2021). China’s Foreign Oil Dependence Soars to 73\%. https://www.china5e.com/news/news-1110148-1.html

Correlje, A., \& Van der Linde, C. (2006). Energy Supply Security and Geopolitics: A European Perspective. Energy Policy, 34, 532-543. https://doi.org/10.1016/j.enpol.2005.11.008

Deutch, J., Schlesinger, J. R., \& Victor, D. G. (2006). National Security Consequences of US Oil Dependency. Independent Task Force Report No. 58, Council on Foreign Relations.

Downs, E. (2019). High Anxiety: The Trade War and China's Oil and Gas Supply Security. https://globallnghub.com/wp-content/uploads/2019/11/ChinaTradeWar CGEP Com mentary 111219-3.pdf

Downs, E. S. (2004). The Chinese Energy Security Debate. The China Quarterly, 177, 21-41. https://doi.org/10.1017/S0305741004000037

Downs, E. S. (2006). China. In Brookings Foreign Policy Studies (Ed.), Energy Security Series (pp. 1-67). The Brookings Institution.

Downs, E. S. (2008). China's "New" Energy Administration. http://www.frankhaugwitz.eu/doks/policy/2008 11 China NEA Brookings.pdf

Downs, E. S. (2010). Who Is Afraid of China's Oil Companies? In C. Pascual, \& J. Elkind (Eds.), Energy Security: Economic, Politics, Strategies, and Implications (pp. 73-102). Brookings Institution Press.

Downs, E. S., \& Meidan, M. (2012). Business and Politics in China: The Oil Executive Reshuffle of 2011. The Brookings Institution.

https://www.brookings.edu/wp-content/uploads/2016/06/Download-the-article.pdf

Duan, F., Ji, Q., Liu, B.-Y. et al. (2018). Energy Investment Risk Assessment for Nations along China's Belt \& Road Initiative. Journal of Cleaner Production, 170, 535-547. https://doi.org/10.1016/j.jclepro.2017.09.152

EIA (2020). China's Crude Oil Imports Surpassed 10 Million Barrels per Day in 2019. https://www.eia.gov/todayinenergy/detail.php?id=43216

Erickson, A. S, \& Collins, G. B. (2010). China's Oil Security Pipe Dream: The Reality, and Strategic Consequences, of Seaborne Imports. Naval War College Review, 63, 88-112.

Francisco, E. (2013). Petroleum Politics: China and Its National Oil Companies. https://www.ie-ei.eu/Ressources/file/memoires/2013/FRANCISCO.pdf

Frankfurt School (2019). Renewable Energy Investment in 2018 Far Exceeds Fossil Fuel Investment.

https://www.frankfurt-school.de/en/home/newsroom/news/2019/Juni/global-trends-in -renewable-energy-investment

Gallagher, K. P., \& Irwin, A. (2014). Exporting National Champions: China's Outward Foreign Direct Investment Finance in Comparative Perspective. China and World Economy, 22, 1-21. https://doi.org/10.1111/cwe.12089 
Glaser, C. L. (2013). How Oil Influences US National Security. International Security, 38, 112-146. https://doi.org/10.1162/ISEC a 00137

GOV.CN (2012). China's Energy Policy 2012.

http://english.www.gov.cn/archive/white paper/2014/09/09/content 281474986284499 htm\#: :text=It\%20has\%20built\%20up\%20a,use\%20conditions\%20have\%20markedly \%20improved

IEA (2017). Renewables 2017: Analysis and Forecasts to 2022. IEA.

IEEFA (2017). China's Global Renewable Energy Expansion. https://ieefa.org/wp-content/uploads/2017/01/Chinas-Global-Renewable-Energy-Expa nsion January-2017.pdf

International Crisis Group (2008). China's Thirst for Oil. Crisis Group Asia Report, Nr. 153.

Jakobson, L., \& Knox, D. (2010). New Foreign Policy Actors in China. Stockholm International Peace Research Institute Policy Paper, No. 26.

Jiao, J.-L., Han, K.-Y., Wu, G. et al. (2014). The Effect of an SPR on the Oil Price in China: A System Dynamics Approach. Applied Energy, 133, 363-373.

https://doi.org/10.1016/j.apenergy.2014.07.103

Koga, K. (2018). The Concept of “Hedging” Revisited: The Case of Japan's Foreign Policy Strategy in East Asia’s Power Shift. International Studies Review, 20, 633-660.

Kong, B. (2010). China’s International Petroleum Policy. Praeger Security International.

Kong, B. (2019). Modernization Through Globalization: Why China Finances Foreign Energy Projects Worldwide. Palgrave Pivot. https://doi.org/10.1007/978-981-13-6016-9

Kong, B., \& Gallagher, K. P. (2017). Globalizing Chinese Energy Finance: The Role of Policy Banks. Journal of Contemporary China, 26, 834-851. https://doi.org/10.1080/10670564.2017.1337307

Kuik, C. C. (2008). The Essence of Hedging: Malaysia and Singapore's Response to a Rising China. Contemporary Southeast Asia, 30, 159-185. https://doi.org/10.1355/CS30-2A

Lake, D. (1996). Anarchy, Hierarchy, and the Variety of International Relations. International Organization, 50, 1-33. https://doi.org/10.1017/S002081830000165X

Li, R., \& Leung, G. C. K. (2011). The Integration of China into the World Crude Oil Market Since 1998. Energy Policy, 39, 5159-5166.

https://doi.org/10.1016/j.enpol.2011.05.048

Liao, J. X. (2015). The Chinese Government and the National Oil Companies (NOCs): Who Is the Principal? Asia Pacific Business Review, 21, 44-59. https://doi.org/10.1080/13602381.2014.939893

Lim, D., \& Cooper, Z. (2015). Reassessing Hedging: The Logic of Alignment in East Asia. Security Studies, 24, 696-727. https://doi.org/10.1080/09636412.2015.1103130

Lind, J., \& Press, D. G. (2018). Markets or Mercantilism? How China Secures Its Energy Supplies. International Security, 42, 170-204. https://doi.org/10.1162/isec a 00310

Liu, C. Q., \& Jiang, X. F. (2020). Domestic and International Oil and Gas Industry Development Report. Petroleum Industry Press.

Medlock, K. B. (2015). To Lift or Not to Lift? The US Crude Oil Export Ban: Implications for Price and Energy Security. The James A. Baker III Institute for Public Policy of Rice University.

http://bakerinstitute.org/research/lift-or-not-lift-us-crude-oil-export-ban-implicationsprice-and-energy-security/ 
Miao, H., Ramchander, S., Wang, T. Y. et al. (2017). Influential Factors in Crude Oil Price Forecasting. Energy Economics, 68, 77-88. https://doi.org/10.1016/j.eneco.2017.09.010

Monique, T. (2012). China's Oil Industry: Corporate Governance with Chinese Characteristics. In Y.-C. Xu (Ed.), The Political Economy of State-owned Enterprises in China and India (pp. 69-93). New York: Palgrave Macmillan.

https://doi.org/10.1057/9781137271655 4

Murphy, A. M. (2010). Beyond Balancing and Bandwagoning: Thailand's Response to China's Rise. Asian Security, 6, 1-27. https://doi.org/10.1080/14799850903471922

NDRC (2015). Guidelines on Strengthening the Operation and Management of Commercial Crude Oil Reserves for Crude Oil Processing Enterprises. https://www.ndrc.gov.cn/fzggw/jgsj/yxj/sjdt/201501/t20150128 987659 ext.html

NDRC (2017). Energy Production and Consumption Revolution Strategy (2016-2030). https://www.ndrc.gov.cn/xxgk/zcfb/tz/201704/t20170425 962953.html

NEA (2014). The Energy Development Strategy Action Plan (2014-2020). http://www.nea.gov.cn/2014-12/03/c 133830458.htm

OECD/IEA (2015). Update on Overseas Investments by China's National Oil Companies. https://www.oecd-ilibrary.org/docserver/9789264247505-en.pdf?expires $=1565893482 \&$ $\underline{\mathrm{id}=\mathrm{id} \& \mathrm{accname}=\mathrm{ocid} 54016459 \& \mathrm{checksum}=\mathrm{A} 2122 \mathrm{C} 1027973 \mathrm{C} 4 \mathrm{E} 6 \mathrm{DA} 9 \mathrm{~F} 72 \mathrm{C} 5 \mathrm{C} 4781 \mathrm{C} 5}$

Paravantis, J. A., \& Kontoulis, N. (2020). Energy Security and Renewable Energy: A Geopolitical Perspective. In M. Al Qubeissi et al. (Eds.), Renewable Energy-Resources, Challenges and Applications. IntechOpen.

https://doi.org/10.5772/intechopen.91848

Patey, L. (2014). The New Kings of Crude: China, India, and the Global Struggle for Oil in Sudan and South Sudan (pp. 82-84). Hurst \& Company.

Shell International B.V. and DRC (2020). China's Energy Revolution in the Context of the Global Energy Transition (p. 43). Springer.

Shi, B. Y., \& Cai, T. (2020). Has China's Oil Investment in Belt and Road Initiative Countries Helped Its Oil Import? Energies, 13, 3176. https://doi.org/10.3390/en13123176

Singh, M. (2012). China's Strategic Petroleum Reserves: A Reality Check. Institute for Defence Studies and Analyses (IDSA), Issue Brief.

https://idsa.in/system/files/IB ChinasStrategicPetroleumReserves MandipSingh 210512.pdf

Sohu News (2015). Speed up the Improvement of the Petroleum Strategic Reserve System. http://news.sohu.com/20150210/n408902745.shtml

Sullivan, M. (2013). The Entanglement of Energy, Grand Strategy, and International Security. In A. Goldthaul (Ed.), The Handbook of Global Energy Policy (pp. 30-47). Wiley-Blackwell. https://doi.org/10.1002/9781118326275.ch2

Tessman, B., \& Wolfe, W. (2011). Great Powers and Strategic Hedging: The Case of Chinese Energy Security Strategy. International Studies Review, 13, 214-240. https://doi.org/10.1111/j.1468-2486.2011.01022.x

Tunsjø, Ø. (2013). Security and Profit in China's Energy Policy: Hedging against Risk (p. 37). Columbia University Press.

https://doi.org/10.7312/columbia/9780231165082.003.0003

Vivoda, V. (2009). Diversification of Oil Import Sources and Energy Security: A Key Strategy or an Elusive Objective? Energy Policy, 37, 4615-4623.

https://doi.org/10.1016/j.enpol.2009.06.007

Wang, C. N. (2021). China's Investments in the Belt and Road Initiative (BRI) in 2020 (pp. 1-26). IIGF Green BRI Center.

Wang, J., Sun, X. L., Li, J. P. et al. (2018). Has China's Oil-Import Portfolio Been Opti- 
mized from 2005 to 2014? A Perspective of Cost-risk Tradeoff. Computers \& Industrial Engineering, 126, 451-464. https://doi.org/10.1016/j.cie.2018.10.005

Wang, K.-H., Su, C.-W., \& Umar, M. (2021). Geopolitical Risk and Crude Oil Security: A Chinese Perspective. Energy, 219, Article ID: 119555.

https://doi.org/10.1016/j.energy.2020.119555

Wang, S. (2020). Clean Energy Does Not End the Energy Security Game-It Reshuffles the Deck. The Breakthrough Institute. 29 September. https://thebreakthrough.org/issues/energy/clean-energy-security

Wolfe, W. M., \& Tessman, B. F. (2012). China’s Global Equity Oil Investments: Economic and Geopolitical Influences. Journal of Strategic Studies, 35, 175-196. https://doi.org/10.1080/01402390.2011.635467

Wood Mackenzie (2020). China's Crude Reserves to Reach 1.15 Billion Barrels in 2020. https://www.woodmac.com/press-releases/chinas-crude-reserves-to-reach-1.15-billionbarrels-in-2020/

World Energy Outlook (2018). https://www.iea.org/reports/world-energy-outlook-2018

Wu, K. (2013). Energy Economy in China: Policy Imperatives, Market Dynamics, and Regional Developments. World Scientific Publishing Co. Pte. Ltd.

XinhuaNet (2014). The Sixth Plenary Meeting of the Leading Group for Financial and Economic Affairs.

http://www.xinhuanet.com//video/2014-06/13/c 126616850.htm?from=timeline\&isapp installed $=0$

XinhuaNet (2015). Xi Jinping Presided over the Ninth Meeting of the Central Financial and Economic Leading Group.

http://www.xinhuanet.com/politics/2015-02/10/c 1114322773.htm

XinhuaNet (2020). Xi's Statement at the General Debate of the 75th Session of the United Nations General Assembly. http://www.xinhuanet.com/english/2020-09/23/c 139388686.htm

$\mathrm{Xu}, \mathrm{Q}$. H., \& Chung, W. (2016). China's Energy Policy from National and International Perspectives: The Energy Revolution and One Belt One Road Initiative (p. 25). City University of HK Press.

Yergin, D. (2006). Ensuring Energy Security. Foreign Affairs, 85, 69-82. https://doi.org/10.2307/20031912

Yu, H. Y. (2011). Oil Reserve to Reach 85m Tons by 2020. China Daily.

Zhao, Y., Shi, X. P., \& Song, F. (2020). Has Chinese Outward Foreign Direct Investment in Energy Enhanced China's Energy Security? Energy Policy, 146, Article ID: 111803. https://doi.org/10.1016/j.enpol.2020.111803

Zheng, Y. H. (2017). Evaluating China's Oil Security and Overseas Oil Investment. American Journal of Industrial and Business Management, 7, 959-972. https://doi.org/10.4236/ajibm.2017.78069

Zhu, T., \& Wang, L. (2020). State Energy Transition: German and American Realities and Chinese Choices. Springer Nature Singapore Pte Ltd. https://doi.org/10.1007/978-981-32-9499-8 